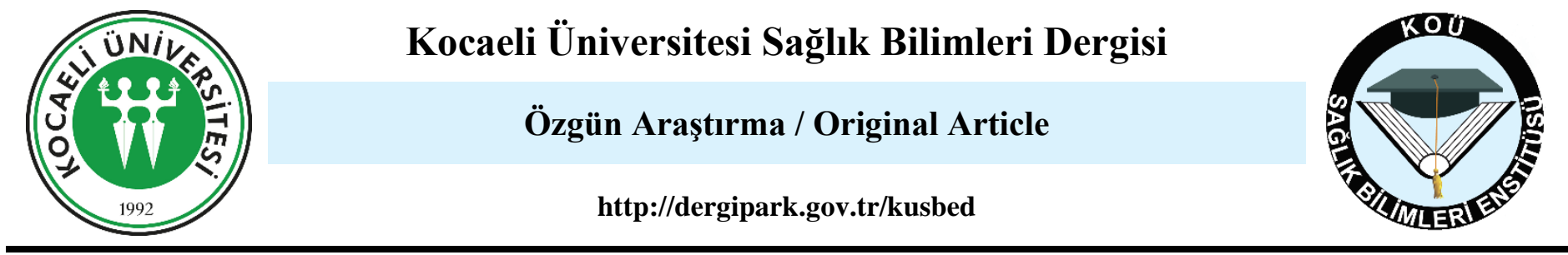

\title{
EXAMINING THE IMPACT OF COVID-19 PANDEMIC ON PREGNANT WOMEN'S PRENATAL CARE DEMAND: A CROSS-SECTIONAL SURVEY
}

\author{
COVID-19 PANDEMISININ GEBELERIN DOĞUM ÖNCESİ BAKIM TALEPLERİ ÜZERINDEKI \\ ETKISININ INCELENMESI: KESITTSEL BIR ARAŞTIRMA
}

Deniz Aky1ldız ${ }^{* 1}$

${ }^{1}$ Kahramanmaras Sutcu Imam University, Faculty of Health Sciences, Department of Midwifery, Kahramanmaras, Turkey

ORCID iD: Deniz Aky1ldı: 0000-0001-8548-0485

*Sorumlu Yazar / Corresponding Author: Deniz Akyıldız e-posta / e-mail: denizbtm@ gmail.com

Geliş Tarihi / Received: 30.05.2021

Kabul Tarihi / Accepted: 29.07.2021

Yaymm Tarihi / Published: 31.10 .2021

\begin{abstract}
Objective: The study aimed to examine the impact of the COVID-19 pandemic on pregnant women's prenatal care demand.

Methods: This cross-sectional study was conducted between July 2020 and November 2020. The sample included 370 pregnant women recruited using the convenience sample method. The research data were collected by face-to-face interview technique with the questionnaire form prepared by the researcher using the literature on the subject. The data were analyzed using the chi-square test, fisher's exact test, student t-test, and oneway ANOVA test. A $p<0.05$ was considered statistically significant.

Results: The average number of prenatal care was $1.7 \pm 1.4$, the average prenatal care initiation time was $23.1 \pm 8.5$ weeks, and $69.6 \%$ got inadequate prenatal care during their pregnancy. The rate of having COVID-19 disease in pregnant women taking part in the study was $1.9 \%$. Of women, $77.6 \%$ had fear of contracting COVID-19 disease, 70\% fear of transmitting COVID-19 to her fetus, and $60.3 \%$ fear about carrying COVID-19 from hospital to home. It was determined that pregnant women who were worried about getting COVID-19 disease, their babies were infected with COVID-19 and carrying COVID-19 from hospital to home received less prenatal care than those who did not live, had lower rates of receiving adequate prenatal care, and delayed receiving prenatal care.

Conclusion: It was determined that the COVID-19 pandemic had adversely affected the prenatal care demand. The study has important strengths as it is one of the first studies on prenatal care that is one of the determinants of maternal and fetal health.
\end{abstract}

Keywords: Coronavirus, COVID-19, midwifery care, pregnancy, prenatal care

\section{Öz}

Amaç: Araştırmanın amacı COVID-19 pandemisinin gebe kadınların doğum öncesi bakım (DÖB) talepleri üzerindeki etkisini belirlemektir.

Yöntem: Temmuz 2020 ve Kasım 2020 tarihleri arasında kesitsel olarak yapılan araştırmaya olasılıksız örnekleme yöntemi ile 370 gebe alındı. Araştırma verileri araştırmacı tarafindan konuya ilişkin literatürden yararlanılarak hazırlanan bilgi formu ile yüz yüze görüşme tekniğiyle toplandı. Elde edilen veriler ki-kare testi, fisher's exact testi, student t-test ve one-way ANOVA testlerleri kullanılarak analiz edildi ve $p<0,05$ istatistiksel olarak anlamlı kabul edildi.

Bulgular: Araştırma kapsamındaki gebelerin aldıkları DÖB sayı ortalaması 1,7 $\pm 1,4$ ve doğum öncesi bakıma başladıkları zaman ortalaması 23,1 $\pm 8,5$ gestasyonel hafta idi. Gebelerin \%69,6'sının gebelikleri süresince yetersiz doğum öncesi bakım aldıkları belirlendi. Kadınların \%77,6'sı COVID-19 hastalığına yakalanma korkusu, \%70'i COVID-19'u bebeğine bulaştırma korkusu ve \%60,3'ü hastaneden eve COVID-19 taşıma korkusu yaşadıklarını bildirdi. COVID-19 hastalığına yakalanma endişesi, bebeğine COVID-19 bulaşır endişesi ve hastaneden eve COVID-19 taşıma endişesi yaşayan gebelerin yaşamayanlara göre daha az sayıda doğum öncesi bakım aldıkları, yeterli doğum öncesi bakım alma oranları daha düşük olduğu ve doğum öncesi bakım alma sürelerinin geciktiği saptandı.

Sonuç: COVID-19 pandemisinin doğum öncesi bakım talebini olumsuz etkilediği belirlendi. Bu bulgu, pandeminin anne ve fetüs sağlı̆̆ üzerinde önemli bir yere sahip olan doğum öncesi bakım talebine etkisini ortaya koyan ilk çalışma olması açısından önemlidir.

Anahtar Kelimeler: Koronavirüs, COVID-19, ebelik bakımı, gebelik, doğum öncesi bakım. 


\section{Introduction}

Coronavirus disease 2019 (COVID-19) had led to the deadliest pandemic in over 100 years and caused deaths globally. ${ }^{1,2}$ There have been 100.819 .363 confirmed cases of COVID-19, including 2.176.159 deaths, reported to World Health Organization (WHO). ${ }^{3}$ Following the rapid spread of the disease in many countries, including Turkey, have been taken to prevent the spread of special measures such as physical distance and quarantined. The first case was in Turkey in March 2020 and reported to the health institutions are not required, except in cases of emergency. Besides all these precautions and quarantine practices, focus on COVID-19 and fear of getting COVID-19 disease can distract pregnant women from routine prenatal care (PNC). ${ }^{4,5}$ One study reported that as the COVID-19 pandemic continues, PNC could decrease by $51.9 \%$ because of the reduced healthcare workforce, resources, demand, and access. $^{6}$

Studies have found that pregnant have expressed fears about getting infected, both for themselves and their babies. ${ }^{7,8}$ In a qualitative study conducted in our country, it was determined that the coronavirus epidemic caused anxiety, distress, and fear in pregnant women. ${ }^{9}$ People avoid situations they fear. Fear increases the protection and avoidance actions against the situation the person finds dangerous. ${ }^{10}$ Based on these findings, the fears of COVID19 may cause a decrease in the demand for pregnant women to receive PNC. The care deficiency during pregnancy can be quite harmful to maternal and fetal health. ${ }^{4,11}$

The United Nations Millennium Development Goals include improving maternal health and reducing neonatal deaths. ${ }^{12}$ Receiving adequate PNC contributes positively to maternal and neonatal health during pregnancy, birth, and postnatal periods. ${ }^{13-17}$ Thus, in order to reduce maternal and neonatal mortality and morbidity rates, all women should receive regular and adequate PNC throughout their pregnancy. ${ }^{10}$ Besides this situation, it is important that pregnant women during the pandemic process take measures to protect themselves against COVID-19 and receive care to report signs of infection to healthcare professionals. ${ }^{5}$

Therefore, it is very important to determine the number of pregnant women taking PNC and the conditions that reduce it and to take precautions. The Republic of the Turkey Ministry of Health was reported in 2014 that at least four PNC should be arranged by a health professional during pregnancy. ${ }^{18}$ Besides this recommendation, WHO had proposed six PNC programs, including three face-to-face and three remote contacts during the COVID-19 pandemic. $^{19}$ Another criterion, which is as important as receiving adequate $\mathrm{PNC}$, is the first follow-up in the early pregnancy week. ${ }^{20}$ In the COVID-19 pandemic, WHO recommended that pregnant women receive PNC at the 12 th week. ${ }^{19}$

Studies show that various situations such as demographic factors, obstetric characteristics, economic difficulties, not knowing the importance of PNC, not being able to access health services, not being aware of services reduce the demand of pregnant women for PNC. ${ }^{21-24}$ Besides these findings, pregnant women may have decreased demand for PNC in the COVID-19 pandemic for various reasons. Within my knowledge, there is no study that evaluated the effects of the COVID-19 on PNC demand. It is vital to determine the PNC demand status of pregnant women and to offer appropriate PNC models to prevent complications due to the pandemic. The aim of this study is to examine the impact of the COVID-19 pandemic on pregnant women's
PNC demand. The purposes of this investigation were; 1) to determine the PNC competence, the number of received PNC, and PNC initiation time, 2) to determine the fears and experiences of pregnant women about COVID-19, and 3) to identify factors related the PNC competence, the number of received $\mathrm{PNC}$, and $\mathrm{PNC}$ initiation time.

\section{Methods}

\section{Study Design and Setting}

The research was carried out as a cross-sectional study at an obstetrics and pediatrics hospital in Kahramanmaras province in Turkey between 13 July 2020 and 27 November 2020. Three hundred seventy pregnant women determined by convenience sample method were included in the study.

\section{Sampling Method}

The number of people who needed to be sampled was calculated using the non-probability sampling technique. The number of pregnant women who went to the hospital a year ago was 9896. The minimum number of individuals to be included in the sampling was calculated with a $95 \%$ confidence interval $(\alpha=0.05), \quad p=0.050, \quad$ and $\mathrm{N}=9896$ population numbers and found 370 .

\section{Inclusion and Exclusion Criteria}

The inclusion criteria comprised being over 18 years of age, able to speak and understand Turkish, have not been diagnosed with COVID-19, residency in Kahramanmaras, agreeing to take part in the research. The exclusion criteria were that the pregnant woman did not answer all the study questions and wanted to exit the study.

\section{Data Collection}

The researcher collected the research data through face-toface interviews with pregnant women who applied for policlinic examination during working hours. Research data was collected by a questionnaire form. The questionnaire form comprised 21 questions prepared by the researcher based on the literature. ${ }^{2,7,8}$ The form had three parts. In the first part, there were 12 questions examining sociodemographic and obstetric characteristics. In the second part, there were 9 questions about PNC demand and fears and experiences of pregnant women about COVID-19. To evaluate the PNC demand; The questionnaire form contained questions on the PNC competence (adequate or inadequate), the number of received PNC, and PNC initiation time.

In the survey, criteria of the Republic of the Turkey Ministry of Health PNC Management Guide were used to determine PNC as "adequate" or "inadequate". According to these criteria, it is stated that at least 4 follow-ups should be examined by a health professional during pregnancy. It is suggested that the first follow-up should be in the first 14 weeks, the second follow-up should be in an 18-24th gestational week $(\mathrm{GW})$, followed by the third in 28-32th GW and the fourth follow-up should be in a 36-38th week.18 Based on this information, it evaluated pregnant women based on follow-ups number they should take according to the current week of pregnancy as "adequate" and "inadequate".

\section{Dependent and Independent Variables}

The dependent variables of the study are the PNC competence, the number of received PNC, and PNC initiation time. Independent variables were determined as 
sociodemographic characteristics, obstetric characteristics, fears, and experiences of pregnant women about COVID-19.

\section{Statistical analysis}

The data was analyzed using the SPSS 21.0 program. The measured values were given as number, percentage and mean +/- standard deviation (SD). The chi-square test, Fisher's exact test, Student t test, and One-way ANOVA were used to evaluate factors affecting the PNC demand and the significance level was expressed as $\mathrm{p}<0.05$.

\section{Results}

A total of 644 pregnant women were interviewed during the data collection process of the research. Of these, it could not include 178 of them in the study because they could not speak and understand Turkish, 7 were illiterate, 37 did not agree to participate in the study, and 52 were under the age of 18. As a result, the study was completed with 370 pregnant women (Figure 1).

It was observed that $49.5 \%$ of the pregnant women taking part in the study were between the ages of 29-39. Of the women, $42.4 \%$ graduated from primary school, $80.8 \%$ were not working, and $29.7 \%$ lived in rural areas. Most of the pregnant women $(51.9 \%)$ were in the third trimester of their pregnancy and $(70.5 \%)$ were multiparous. Of the women, $28.4 \%$ said they had not planned their pregnancies and $9.5 \%$ said they had not wanted to be pregnant. Other sociodemographic and obstetric characteristics are shown in Table 1.

Table 2 shows the characteristics of pregnant women regarding their PNC demand. The mean PNC number of the women taking part in the study was $1.7 \pm 1.4$ (range: $1-8$ ) and the mean PNC initiation time was $23.1 \pm 8.5$ (range: 12 40 ). It was determined that $69.6 \%$ of the pregnant women taking part in the study obtained inadequate PNC during their pregnancy. Of women, $56.2 \%$ said that they received PNC from a gynecologist, $66.7 \%$ from the internet, and $54.3 \%$ from a state hospital.

The rate of having COVID-19 disease in pregnant women taking part in the study was $1.9 \%$. Of women, $77.6 \%$ had fear of contracting COVID-19 disease, $70.0 \%$ fear of transmitting COVID-19 to her fetus, and $60.3 \%$ fear about carrying COVID-19 from hospital to home (Table 3).

It gave the results for determining the sociodemographic and obstetric factors affecting PNC demand in pregnant women in Table 4. There was a significant difference between the PNC competence $(p=0.04)$, the number of received PNC $(p=0.045)$, mean PNC initiation time $(p=0.017)$, and educational level. Pregnant women who had no other living children had higher rates of receiving adequate PNC $(71.0 \%$ and $29.0 \%, p<0.05$ respectively), the mean of received PNC number $(1.86 \pm 1.65$ and $1.43 \pm 0.79, p<0.05$, respectively), and the mean of PNC initiation time $(21.0 \pm 8.0$ and $24.3 \pm$ $8.6, p<0.05$, respectively) compared to those with children.

It was determined that there was no relationship between the PNC competence $(p=0.122)$, the number of received PNC $(p=0.186)$, PNC initiation time $(p=0.665)$, and having COVID-19 disease during pregnancy. Women who had a fear of contracting COVID-19 disease, fear of transmitting COVID-19 to their fetus, and fear about carrying COVID-19 from hospital to home had lower rates of getting adequate PNC than those who did not $(p<0.01)$. There was a significant statistical relationship between fear of contracting COVID-19 disease $(p<0.05)$, fear of transmitting COVID-19 to their fetus $(p<0.05)$, fear about carrying COVID-19 from hospital to home $(p<0.01)$, and the number of received PNC. It was also found that fears related to COVID-19 significantly delayed the PNC initiation time (Table 5).

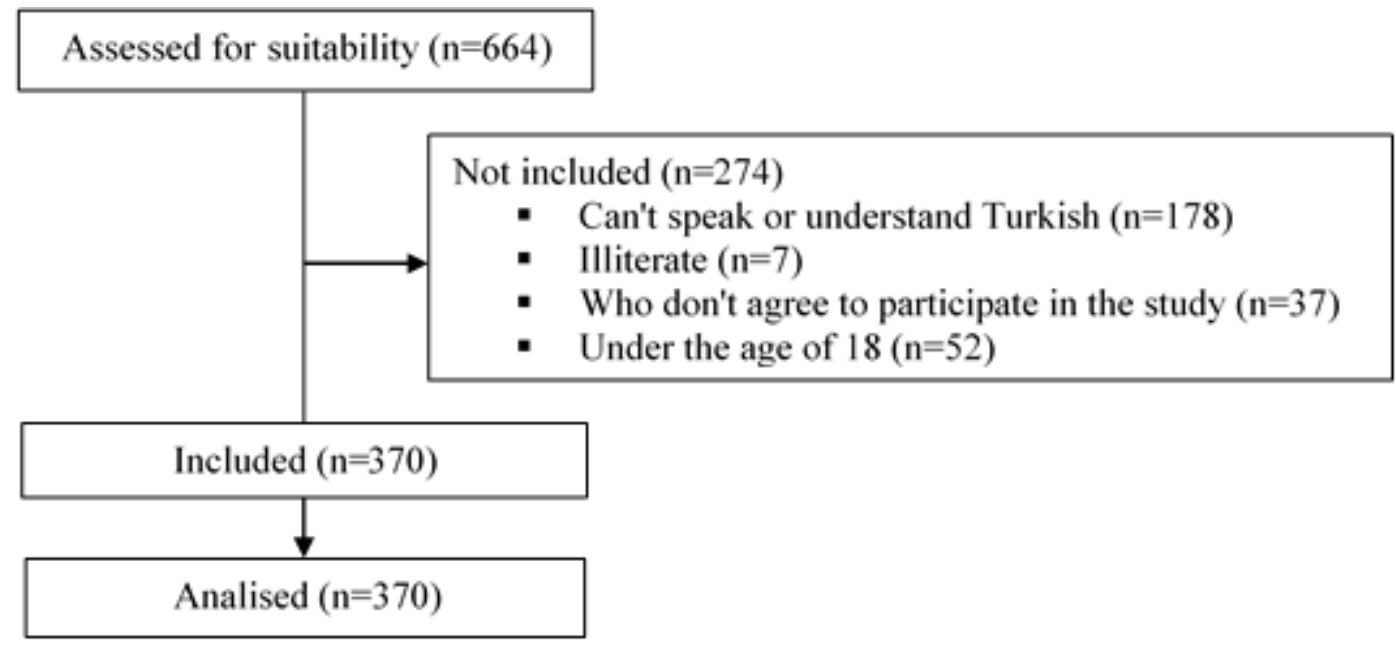

Figure. 1. Diagram of the research process. 
Table 1. Sociodemographic and obstetric characteristics of pregnant women $(\mathrm{N}=370)$.

\begin{tabular}{|c|c|}
\hline Variables & n (\%) \\
\hline $\begin{array}{l}\text { Age } \\
18-28 \\
29-39 \\
40-50\end{array}$ & $\begin{array}{c}177(47.8) \\
183(49.5) \\
10(2.7)\end{array}$ \\
\hline $\begin{array}{l}\text { Educational level } \\
\text { Primary school } \\
\text { Middle school } \\
\text { High school } \\
\text { University }\end{array}$ & $\begin{array}{c}157(42.4) \\
111(30.0) \\
74(20.0) \\
28(7.6)\end{array}$ \\
\hline $\begin{array}{l}\text { Pregnant women's occupation } \\
\text { Housewife } \\
\text { Civil servant } \\
\text { Worker }\end{array}$ & $\begin{array}{c}299(80.8) \\
43(11.6) \\
28(7.6)\end{array}$ \\
\hline $\begin{array}{l}\text { Place of residence } \\
\text { Urban } \\
\text { Rural }\end{array}$ & $\begin{array}{l}260(70.3) \\
110(29.7)\end{array}$ \\
\hline $\begin{array}{l}\text { Income level } \\
\text { Income is lower than expenses } \\
\text { Income is equal to expenses }\end{array}$ & $\begin{array}{l}125(33.8) \\
245(66.2)\end{array}$ \\
\hline $\begin{array}{l}\text { Marital status } \\
\text { Married } \\
\text { Single }\end{array}$ & $\begin{array}{c}353(95.4) \\
17(4.6)\end{array}$ \\
\hline $\begin{array}{l}\text { Trimester of pregnancy } \\
\text { First trimester } \\
\text { Second trimester } \\
\text { Third trimester }\end{array}$ & $\begin{array}{l}48(13.0) \\
130(35.1) \\
192(51.9)\end{array}$ \\
\hline $\begin{array}{l}\text { Total number of pregnancies } \\
\text { Primipary } \\
\text { Multiparous }\end{array}$ & $\begin{array}{l}109(29.5) \\
261(70.5)\end{array}$ \\
\hline $\begin{array}{l}\text { Pregnancy planning status } \\
\text { Planned } \\
\text { Not planned }\end{array}$ & $\begin{array}{l}265(71.6) \\
105(28.4)\end{array}$ \\
\hline $\begin{array}{l}\text { Status of wanting pregnancy } \\
\text { Wanted } \\
\text { Not wanted }\end{array}$ & $\begin{array}{c}335(90.5) \\
35(9.5)\end{array}$ \\
\hline $\begin{array}{l}\text { Parental status } \\
\text { Have other children } \\
\text { No other children }\end{array}$ & $\begin{array}{l}239(64.6) \\
131(35.4)\end{array}$ \\
\hline
\end{tabular}

Table 2. Some data on prenatal care $(\mathrm{N}=370)$.

\begin{tabular}{l|c}
\hline \multicolumn{1}{c|}{ Variables } & mean \pm SD / n (\%) \\
\hline Number of received PNC, mean (SD), range & $1.7 \pm 1.4(1-8)$ \\
PNC initiation time (GW), mean (SD), range & $23.1 \pm 8.5(12-40)$ \\
Prenatal care competence, n (\%) & \\
$\quad$ Adequate & $93(23.4)$ \\
$\quad$ Inadequate & $277(69.6)$ \\
Information resource in pregnancy*, n (\%) & \\
$\quad$ Midwife & $181(48.9)$ \\
$\quad$ Gynecologist & $281(75.9)$ \\
Family doctor & $166(44.9)$ \\
$\quad$ Internet & $247(66.7)$ \\
The place of received PNC*, n(\%) & \\
$\quad$ State hospital & \\
$\quad$ University hospital & $201(54.3)$ \\
Private hospital & $112(30.3)$ \\
Family health center & $178(48.1)$ \\
\hline
\end{tabular}

GW, Gestational week; PNC, Prenatal care; SD, Standard deviation. *The data has been folded as more than one option can be selected. 
Table 3. Fears and experiences of pregnant women about COVID-19 (N=370).

\begin{tabular}{l|c}
\hline Variables & $\mathbf{n}(\%)^{*}$ \\
\hline $\begin{array}{l}\text { Getting COVID-19 during pregnancy } \\
\text { Yes }\end{array}$ & $7(1.9)$ \\
No & $363(98.1)$ \\
\hline $\begin{array}{l}\text { Fear of contracting COVID-19 disease } \\
\text { Yes }\end{array}$ & $287(77.6)$ \\
No & $83(22.4)$ \\
\hline Fear of transmitting COVID-19 to her fetus & $259(70.0)$ \\
$\quad$ Yes & $111(30.0)$ \\
No & \\
\hline $\begin{array}{l}\text { Fear about carrying COVID-19 from hospital to } \\
\text { home }\end{array}$ & \\
Yes & $223(60.3)$ \\
No & $147(39.7)$ \\
\hline
\end{tabular}

*The data has been folded as more than one option can be selected.

Table 4. Comparison of the sociodemographic and obstetric characteristics with PNC demand.

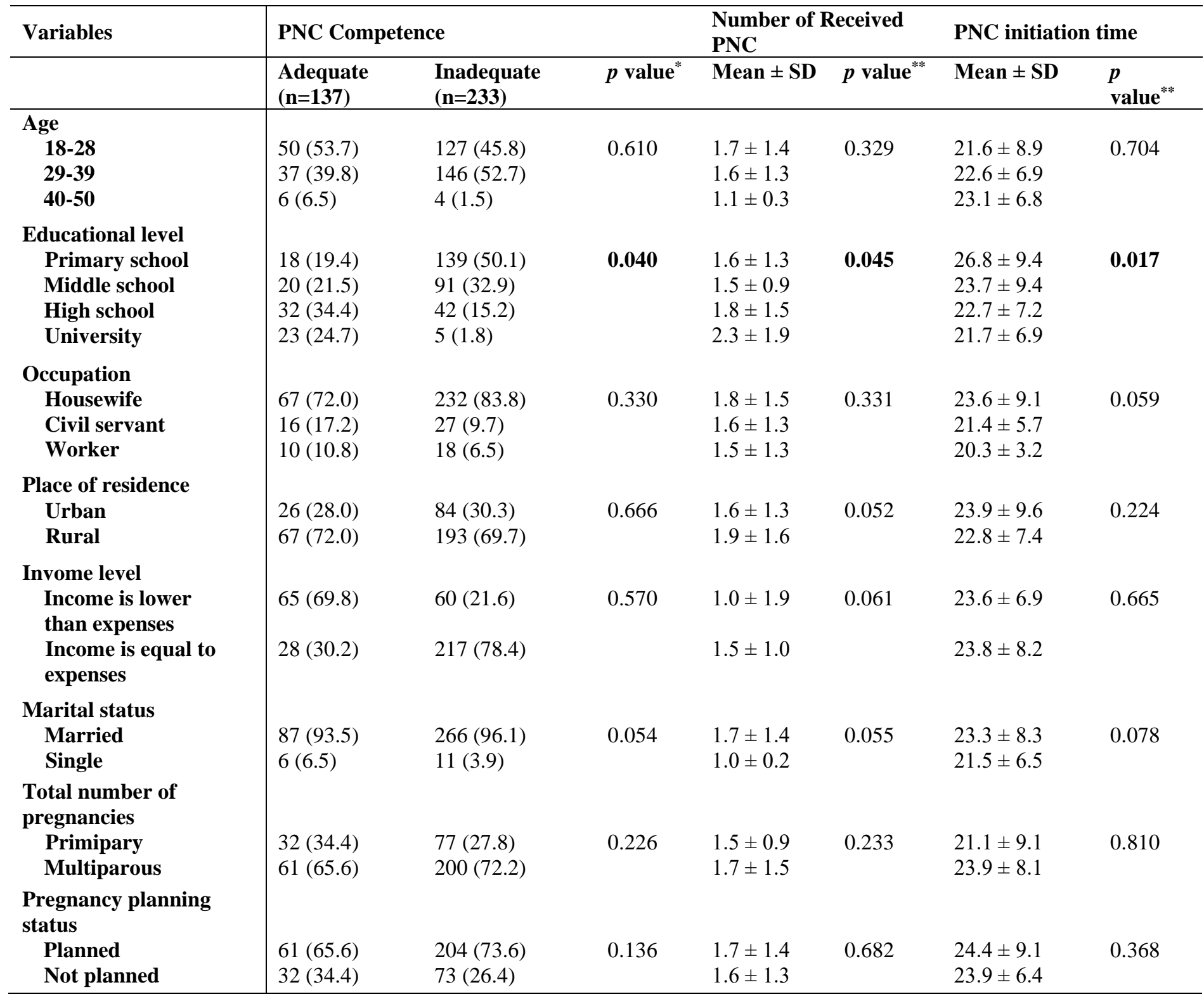


Table 4. Comparison of the sociodemographic and obstetric characteristics with PNC demand (Continuation).

\begin{tabular}{l|lllllll}
\hline $\begin{array}{l}\text { Status of wanting } \\
\text { pregnancy } \\
\text { Wanted }\end{array}$ & $80(86.0)$ & $255(92.1)$ & 0.085 & $1.4 \pm 1.0$ & 0.063 & $23.6 \pm 8.7$ & 0.368 \\
$\quad$ Not wanted & $13(14.09$ & $22(7.9)$ & & $1.6 \pm 1.3$ & & $21.6 \pm 5.7$ & \\
$\begin{array}{c}\text { Parental status } \\
\text { Have other children }\end{array}$ & $27(29.0)$ & $212(76.5)$ & $\mathbf{0 . 0 3 7}$ & $1.4 \pm 0.7$ & $\mathbf{0 . 0 0 5}$ & $24.3 \pm 8.6$ & $\mathbf{0 . 0 1 8}$ \\
$\quad$ No other children & $66(71.0)$ & $65(23.5)$ & & $1.8 \pm 1.6$ & & $21.0 \pm 8.0$ & \\
\hline
\end{tabular}

PNC, Prenatal care. ${ }^{*}$ Chi-square test and Fisher's exact test (frequency <5). ${ }^{* *}$ Student $t$ test and One-way ANOVA test.

Table 5. Comparison of the fears and experiences of COVID-19 with PNC demand (N=370).

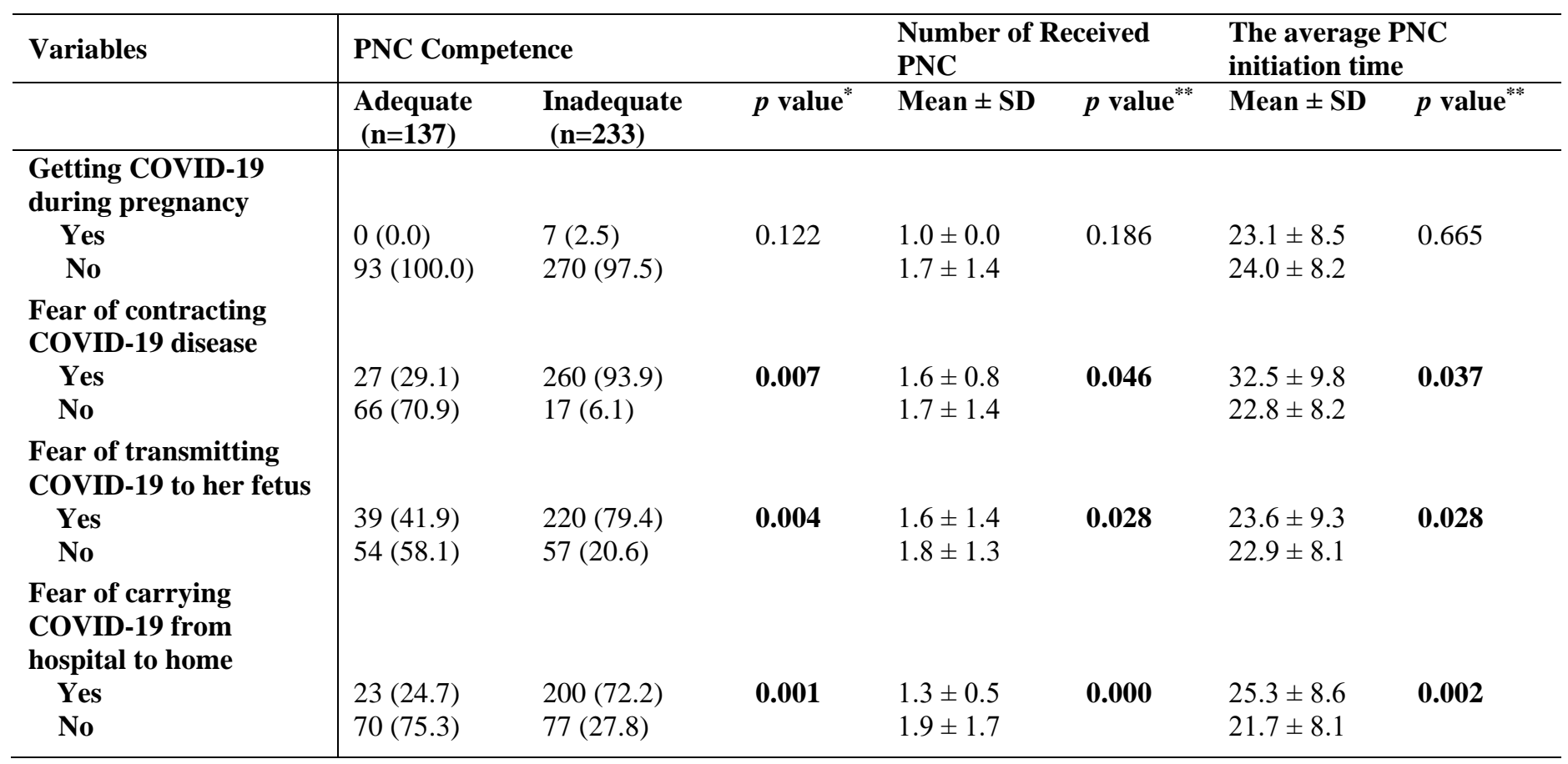

${ }^{*}$ Chi-square test and Fisher's exact test (frequency <5). ${ }^{* *}$ Student $\mathrm{t}$ test.

\section{Discussion}

This research was conducted in Kahramanmaras with 370 pregnant women in order to determine the impact of the COVID-19 pandemic on pregnant women's PNC demand. In the research, it is got that most women did not get adequate $\mathrm{PNC}$, the number of care received during pregnancy is insufficient, and the PNC initiation time is late. It has been determined that most pregnant women were fear of contracting COVID-19 disease, fear of transmitting COVID-19 to their fetus, and fear about carrying COVID-19 from hospital to home. Fears of COVID-19 infection and having a living child negatively affected the PNC competence, the number of received $\mathrm{PNC}$, and $\mathrm{PNC}$ initiation time. These results are important and valuable to reveal information about pregnant women's PNC demand in the COVID-19 pandemic.

The total number of PNC is an important indicator to evaluate the adequacy of PNC. Studies show that receiving an adequate number of PNC had positive effects on maternal health including pregnancy, birth, and postpartum periods, and on the fetal period and the neonatal period. ${ }^{13-17}$ Women are required to receive $\mathrm{PNC}$ at least four times during their pregnancy in Turkey. ${ }^{18}$ Besides this recommendation, WHO had proposed six PNC programs, including three face-to- face and three remote contacts during the COVID-19 pandemic. ${ }^{19}$ Despite these recommendations, the average number of PNC received by pregnant women in this study was 1.7 times. When the studies conducted in our country before the pandemic were examined, it was seen that the average number of PNC received was between 8.0-12.4. ${ }^{25-27}$ According to these findings, it is seen that pregnant women received less than the recommended number of PNC during the pandemic. In addition, when compared with other study findings, it can be said that there is a decrease in the number of PNC during the pandemic period.

The Republic of the Turkey Ministry of Health has reported that at least four PNC should be arranged by a health professional during pregnancy. First care during the first 14 weeks of pregnancy, second care between 18-24th GW, third care between 28-32th GW, and fourth care between 36-38th GW. Pregnant women who provide these conditions are having received adequate PNC. ${ }^{18}$ Data from the Turkey Demographic and Health Survey shows that $90.0 \%$ of pregnant women in Turkey receive adequate PNC. ${ }^{28}$ Tas et al. in their study at the hospital where this study was conducted in Kahramanmaras, the rate of getting PNC of pregnant women was reported as $56.5 \% .^{29}$ The prevalence of adequate PNC in pregnant women was determined as $23.4 \%$ in this study. It is believed that this decrease in the PNC 
demand is related to the effects of the pandemic process. Studies supporting this situation are included in the literature. A study on the pandemic of Ebola virus disease also reported that the rate of PNC decreased by $22 \%$ during the pandemic ${ }^{30}$ Roberton et al. had reported that there would be a $51.9 \%$ decrease in PNC in the continuation of the COVID-19 pandemic process. ${ }^{6}$ Based on these results, it can be said that there was a decrease in the rate of adequate PNC in the COVID-19 pandemic and the pandemic process should be carefully evaluated and managed in terms of PNC. Another criterion, which is as important as receiving adequate PNC, is PNC initiation time. ${ }^{20}$ The Republic of the Turkey Ministry of Health recommends that pregnant women start to PNC until the end of the 14th week of pregnancy. ${ }^{18}$ In the COVID-19 outbreak, WHO recommended that pregnant women receive first care at 12 weeks of gestation. ${ }^{19}$ On the other hand, in this study, the PNC initiation time was 23.1 gestational weeks. This result shows that in late a while compared to previous studies in Turkey. Yücel et al. determined the mean of the first pregnancy follow-up week as 5.5 weeks, Durusoy et al. 7.2 weeks, and Catak et al. 9.1 weeks. ${ }^{26,27,31}$ It can be said that besides the inadequate PNC during pregnancy, there is PNC initiation time was negatively affected in the COVID-19 pandemic.

In the literature, it is observed that pregnant women were concerned about being infected with COVID-19 during transportation, in hospitals, and in public places, other family members carrying the infection, and infecting the fetus. $^{7,32,33}$ In this study, similar to the information in the literature, pregnant women experienced fear of contracting COVID-19 disease, fear of transmitting COVID-19 to their fetus, and fear about carrying COVID-19 from hospital to home. These results reveal that COVID-19 causes a lot of concern and fears in pregnant women.

In this study, there was a statistically significant positive relationship between the PNC competence, the number of received $\mathrm{PNC}$, and $\mathrm{PNC}$ initiation time, and maternal education level. Similarly, there is information in the literature that as the education level of the mother increases, receiving adequate $\mathrm{PNC}$ increases. ${ }^{34,35}$ Besides these results, as the education level of women increases, it may be associated with reaching accurate information about COVID-19 disease during pregnancy.

In this study, fear of contracting COVID-19 disease, fear of transmitting COVID-19 to her fetus, and fear about carrying COVID-19 from hospital to home were the conditions that decrease the receiving adequate $\mathrm{PNC}$, the number of received PNC. Similarly, Fakari and Sinbar reported in their study in Iran that pregnant women could not receive enough PNC because of concerns about infection while being transferred to the hospital. ${ }^{32} \mathrm{Du}$ et al. reported that about $94.6 \%$ of the pregnant women worried about being infected during the COVID-19 in their study conducted in China. ${ }^{7}$ Ravaldi et al. reported in their study in Italy that the fear of pregnant women increased significantly compared to the pre-COVID-19 pandemic. $^{33}$ These results reveal that COVID-19 causes a lot of fear in pregnant women. Besides these findings, it was seen in our study that fears about COVID-19 caused a delay in the PNC initiation time. Our study findings are important because it reveals that the fears of COVID-19 negatively affect the number and competence of PNC, as well as the PNC initiation time.

It was determined that there was no relationship between pregnant women having COVID-19 disease during pregnancy and PNC demand. This can be explained by knowing the effects of COVID-19 during pregnancy. Besides this, pregnant women may have got more health checks to control their own and fetal health. This can be caused because the number of pregnant women who have COVID-19 during pregnancy is quite insufficient.

WHO recommended that three of the six PNC in the COVID-19 pandemic should be provided remote contact at the 20th, 26th, and 38th weeks. ${ }^{19}$ Despite that, this study determined that there was no remote PNC provided by the health professional. All of them received the PNC face to face from private, public, and university hospitals and family health centers. However, a significant portion of the pregnant women taking part in the study stated that they got information from the internet during their pregnancy. It can be ensured that pregnant women receive adequate PNC with remote contact support programs provided by health professionals.

\section{Limitations}

This research has some limitations. First, it conducted the research as cross-sectional; the data got only valid for the time when the research was conducted, it may vary depending on the time. Second, a significant part of the pregnant women at the hospital where the study was conducted were foreign nationals and could not be enrolled in the study because they did not speak Turkish. Depending on this situation, the information got can only represent the sample group and cannot be generalized.

\section{Conclusion}

In this study, it is got that most women did not get adequate $\mathrm{PNC}$, the number of care received during pregnancy is insufficient, and the PNC initiation time is late. It has been determined that most pregnant women were fear of contracting COVID-19 disease, fear of transmitting COVID19 to their fetus, and fear about carrying COVID-19 from hospital to home. Fears of COVID-19 infection and having a living child negatively affected the PNC competence, the number of received PNC, and PNC initiation time. Based on these findings, it can be said that the COVID-19 pandemic negatively affected the PNC demand for pregnant women. It is my opinion that these results are important and valuable to reveal information about pregnant women's PNC demand during the COVID-19 pandemic.

\section{Conflict of Interest}

The author has no conflicts of interest to disclose.

\section{Compliance with Ethical Statement}

For the study, ethical approval was received from Kahramanmaras Sutcu Imam University Faculty of Medicine Clinical Research Ethics Committee (KSU 202012 ; 242) dated 24.06.2020. The pregnant women in the study were informed about the study, and their oral and written consent was got.

\section{Financial Disclosure/Funding}

This study was supported by Kahramanmaras Sutcu Imam University Scientific Research Projects (proposal number 2020/6-18 M).

\section{Author Contributions}

DA: Design, data collection, analysis, literature, manuscript writing, and critical review 


\section{References}

1. Chen H, Guo J, Wang C, Luo F, Yu X, Zhang W, et al. Clinical characteristics and intrauterine vertical transmission potential of COVID-19 infection in nine pregnant women: A retrospective review of medical records. Lancet. 2020;395:809-815. doi:10.1016/S01406736(20)30360-3.

2. Di Mascio D, Khalil A, Saccone G, et al. Outcome of Coronavirus spectrum infections (SARS, MERS, COVID-19) during pregnancy: A systematic review and meta-analysis. AJOG MFM. 2020;2(2):100107. doi:10.1016/j.ajogmf.2020.100107.

3. World Health Organization Coronavirus Disease (COVID-19) Dashboard. URL: https://covid19.who.int/ (Accessed on: February 10, 2021).

4. Masjoudi M, Aslani A, Khazaeian S, Fathnezhad-Kazemi A. Explaining the experience of prenatal care and investigating the association between psychological factors with self-care in pregnant women during COVID-19 pandemic: A mixed method study protocol. Reprod Health. 2020;17(1):1-7. doi:10.1186/s12978-020-00949-0

5. Larki M, Sharifi F, Roudsari RL. Models of maternity care for pregnant women during the COVID-19 pandemic. East Mediterr Health J. 2020;26(9):994-998. doi:10.26719/emhj.20.097.

6. Roberton T, Carter ED, Chou VB, et al. Early estimates of the indirect effects of the COVID-19 pandemic on maternal and child mortality in low-income and middle-income countries: a modelling study. The Lancet Global Health. 2020;8(7):e901e908. doi:10.1016/S2214-109X(20)30229-1

7. Du L, Gu YB, Cui MQ, et al. Investigation on demands for antenatal care services among 2002 pregnant women during the epidemic of COVID-19 in Shanghai. Zhonghua fu Chan ke za zhi. 2020;55(3):160-165. doi:10.3760/cma.j.cn11214120200218-00112.

8. Poon LC, Yang H, Kapur A, et al. Global interim guidance on coronavirus disease 2019 (COVID 19) during pregnancy and puerperium from FIGO and allied partners: Information for healthcare professionals. Int $J$ Gynecol Obstet. 2020;149(3):273-286. doi:10.1002/ijgo.13156.

9. Sahin BM, Kabakci EN. The experiences of pregnant women during the COVID-19 pandemic in Turkey: A qualitative study. Women and Birth. 2020;34(2):162-169. doi:1016/j.wombi.2020.09.022.

10. Ozer EZ, Aksoy M. The impact of fear appeals on the fear of food. Journal of Tourism and Gastronomy Studies. 2018;6(3):359-369. doi:10.21325/jotags.2018.260.

11. Catak B, Oner C, Gulay M, Basturk S, Oguz I, Ozbek R. Prenatal care services in Bursa. Turkish Journal of Family Practice. 2014;18(2):63-69. doi:10.2399/tahd.14.00063.

12. Liu L, Johnson HL, Cousens S, et al. Global, regional, and national causes of child mortality: an updated systematic analysis for 2010 with time trends since 2000. Lancet. 2012;379:2151-61. doi:10.1016/S0140-6736(12)60560-1.

13. Bbaale E. Factors influencing the utilisation of antenatal care content in Uganda. Australas Med J, 2011;4(9):516-526. doi:10.4066/AMJ.2011.849.

14. Liang YW, Chang HP, Lin YH, Lin LY, Chen WY. Factors affecting adequate prenatal care and the prenatal care visits of immigrant women to Taiwan. J Immigr Minor Health. 2014;16:44-52. doi:10.1007/s10903-012-9734-z.

15. Berde AS, Uner S. Adequacy of antenatal care received by Nigerian women and some related factors. TAF Preventive Medicine Bulletin. 2016;15(3):190-198. doi:10.1093/eurpub/cku166.173.

16. Joshi C, Torvaldsen S, Hodgson R, Hayen A. Factors associated with the use and quality of antenatal care in Nepal: A population-based study using the demographic and health survey data. BMC Pregnancy and Childbirth. 2014;14(1):94. doi:10.1186/1471-2393-14-94.

17. Pervin J, Moran A, Rahman M, et al. Association of antenatal care with facility delivery and perinatal survival-a population based study in Bangladesh. BMC Pregnancy and Childbirth. 2012;12:111. doi:10.1186/1471-2393-12-111.

18. T.R. Ministry of Health Public Health Agency of Turkey. URL:

https://sbu.saglik.gov.tr/Ekutuphane/kitaplar/dogumonubakim .pdf (Accessed on: February 12, 2021).

19. World Health Organization (WHO)-United Nations Population Fund. COVID-19 technical brief for maternity services. URL: https://www.unfpa.org/resources/covid-19technical-brief-maternity-services (Accessed on: February 10, 2021).

20. Domingues RMSM, Leal MC, Hartz ZMA, Dias MAB, Vettore MV. Access to and utilizaton of prenatal care services in the Unified Health Sysytem of the city of Rio de Janeiro, Brazil. Revista Brasileira de Epidemiologia. 2013;16(4):953965. doi:10.1590/S1415-790X2013000400015.

21. Yilmaz L, Koruk F, Koruk I. The status of receiving antenatal care services for women who have delivered in a state hospital in Şanliurfa, the quality of these services and related factors. Mersin University Journal of Health Sciences. 2018;11(2):209-218. doi:10.26559/mersinsbd.424153.

22. Aksu S, Akgun T. Prenatal care status and factors of pregnant women in Balıkesir province center. Balıkesir Journal of Health Sciences. 2020;9(3):179-188. https://dergipark.org.tr/tr/pub/balikesirsbd. Accessed February 20, 2021.

23. Jafari F, Eftekhar H, Mohammad K, Fotouhi A. Does group prenatal care affect satisfaction and prenatal care utilization in Iranian pregnant women? Iran $J$ Public Health.2010;39(2):52-62.

https://www.ncbi.nlm.nih.gov/pmc/articles/PMC3481751/. Accessed February 20, 2021.

24. Gregory PA, Heaman MI, Mignone J, Moffatt ME. Predictors of women's satisfaction with prenatal care in a Canadian setting. Matern Child Health J. 2020;24(2):186-195. doi:10.1002/uog.906.

25. Kissal A, Kartal B. The evaluation of prenatal care content of women who gave birth in a university hospital. Journal of Health Sciences of Kocaeli University. 2019;5(1):35-41. doi:10.30934/kusbed.481681.

26. Yucel U, Ciceklioglu M, Ocek ZA, Taner S. Prenatal care utilization level of pregnant women living in three different neighborhoods of Izmir's Bornova district. TAF Preventive Medicine Bulletin. 2015;14(5):370-377. doi:10.5455/pmb.11428673248 .

27. Durusoy R, Davas A, Ergin I, Hassoy H, Tanık FA. Prenatal care utilization from family physicians: A study among pregnant women applying to secondary and tertiary care hospitals in Izmir. Turkish Journal of Public Health. 2011;9(1):1-15. doi:10.20518/tjph.173051.

28. Turkey Demographic and Health Survey (TDHS). Population and health survey. URL: http://www.hips.hacettepe.edu.tr/tnsa2018/rapor/TNSA2018_ ana_Rapor.pdf (Accessed on: February 26, 2020).

29. Tas F, Gülpak M, Oktay AA, Demir N. Receiving care prior to giving birth for women who gave birth at the maternity and children's hospital. KSU Medical Journal. 2019;14(1):24-30. doi:10.17517/ksutfd.487188.

30. Sochas L, Channon AA, Nam S. Counting indirect crisisrelated deaths in the context of a low-resilience health system: the case of maternal and neonatal health during the Ebola epidemic in Sierra Leone. Health Policy Plan. 2017;32(3):329. doi:10.1093/heapol/czx 108 .

31. Catak B, Aksan AD, Zincir M. Quantity and quality of antenatal care services in Karabük community health center. TAF Preventive Medicine Bulletin. 2012;11(2):153-161. doi:10.5455/pmb.20110725054246.

32. Fakari FR, Simbar M. Coronavirus pandemic and worries during pregnancy; A letter to editor. Arch Acad Emerg Med. 2020;(1):e21-e21. http://journals.sbmu.ac.ir/aaem. Accessed February 20, 2021.

33. Ravaldi C, Wilson A, Ricca V, Homer C, Vannacci A. Pregnant women voice their concerns and birth expectations 
during the COVID-19 pandemic in Italy. Women Birth. 2020;1147:9-18. doi:10.1016/j.wombi.2020.07.002.

34. Hawley NL, Brown C, Nu'usolia O, Ah-Ching J, MuasauHoward B, McGarvey ST. Barriers to adequate prenatal care utilization in American Samoa. Matern Child Health J. 2014;18(10):2284-2292. doi:10.1007/s10995-013-1368-9.

35. Partridge S, Balayla J, Holcroft CA, Abenhaim HA. Inadequate prenatal care utilization and risks of infant mortality and poor birth outcome: A retrospective analysis of 28,729,765 US deliveries over 8 years. Am J Perinatol. 2012;29:787-794. doi:10.1055/s-0032-1316439. 